Illinois State University

ISU ReD: Research and eData

Theses and Dissertations

$9-12-2013$

\title{
The Effects Of Planting Techniques On Maize Grain Yield And Silage Production
}

Tyler D. Kaufman

Illinois State University, farmerb7120@aol.com

Follow this and additional works at: https://ir.library.illinoisstate.edu/etd

Part of the Agricultural Science Commons, Agriculture Commons, and the Agronomy and Crop Sciences Commons

\section{Recommended Citation}

Kaufman, Tyler D., "The Effects Of Planting Techniques On Maize Grain Yield And Silage Production" (2013). Theses and Dissertations. 49.

https://ir.library.illinoisstate.edu/etd/49

This Thesis is brought to you for free and open access by ISU ReD: Research and eData. It has been accepted for inclusion in Theses and Dissertations by an authorized administrator of ISU ReD: Research and eData. For more information, please contact ISUReD@ilstu.edu. 


\section{THE EFFECTS OF PLANTING TECHNIQUES ON MAIZE GRAIN YIELD AND SILAGE PRODUCTION \\ Tyler D. Kaufman}

64 Pages

December 2013

This thesis is a comprehensive analysis of the effects of seed orientation, row direction and planting population on grain yield, kernel composition, and silage yield and composition. Producers are striving to increase profit by efficiently using their available land area to maximize crop production. However, little research is available testing the effect of seed orientation on grain or silage production. Quantifying the impacts of seed orientation and row direction on grain and silage is essential for maximum crop production. Dissemination of the results should benefit grain and silage producer.

Two experiments were conducted to evaluate the effects of manipulating seed orientation at planting. In the first experiment, maize yield and kernel composition characteristics were evaluated during the 2011 growing season. The first experiment supported yield increases from controlled manipulation of kernels into the soil. This experiment did support that through alternative planting methods, grain and silage yields can be increased compared to the conventional planting methods that are currently practiced.

In the second experiment, maize grain, kernel composition, silage yield and silage composition were evaluated to observe differences from controlled planting methods 
compared to conventional planting methods during the 2012 growing season. Researchers observed increases in maize grain and silage yield from controlled planting methods compared to conventional planting methods. Differences were observed in direction of leaves in the canopy between planting treatments indicating that plants are able to change the orientation of leaves due to competition of neighboring plants.

These studies suggest controlling seed orientation at planting can increase grain and silage yields with no additional changes to production practices. Additional research is warranted to evaluate differences during different growing conditions of different years and to evaluate hybrid differences for planting treatments. 
THE EFFECTS OF PLANTING TECHNIQUES ON MAIZE GRAIN YIELD AND

SILAGE PRODUCTION

TYLER D. KAUFMAN

A Thesis Submitted in Partial Fulfillment of the Requirements for the Degree of

MASTER OF SCIENCE

Department of Agriculture

ILLINOIS STATE UNIVERSITY 
THE EFFECTS OF PLANTING TECHNIQUES ON MAIZE GRAIN YIELD AND SILAGE PRODUCTION

TYLER D. KAUFMAN

COMMITTEE MEMBERS:

Paul M. Walker, Chair

Rob Rhykerd

Fred Owens 


\section{ACKNOWLEDGMENTS}

For the many people in my life whose patience, knowledge, and support have led to my success and to this academic achievement, I express my sincere appreciation. To my parents, Doug and Angie Kaufman, I thank you for your never ending support. Growing up, you were always there to support me in my decisions; whether right or wrong, you allowed me to learn through my mistakes. You have taught me what it takes to be successful, which has included working hard and caring for others. I thank you for your constant criticism and questioning of my progress to ensure that I'm constantly making progress. These actions have ensured that I'm continually making progress in my life. Thank you for the continuous support and guidance you have provided me throughout the years.

To my grandparents, Gary and Kay Taylor, Harold Kaufman, and Karen Jordan, your support and enthusiasm for of my achievements has kept me motivated. To see how proud each and every one of you are of my accomplishments has provided me the motivation required to continue my education. The pride that you have shown me as a grandson is evident and allows me to continue to thrive in making the best decisions possible. I cannot express, enough, how grateful I am to have all of you in my life. 
To my friends, Matt Faulkner and Austin Omer, your academic support and knowledge has been of great assistance to me. The two of you have helped tremendously in assisting in my writing and data collection over the past few years. You guys made me think in ways that I have never thought before and it has led to the position I am in currently by helping me broaden my horizons as a student and a person.

Dr. Paul Walker, I thank you for allowing me the opportunity to work with you and continue my education. The constant criticisms of my procrastination were much appreciated and kept me motivated to continue working. I greatly appreciate your willingness to work with me and that you saw potential in me as a student. Your knowledge and help have been greatly appreciated.

Dr. Fred Owens, I'm most appreciative for the opportunity to work with you the past two years. It has been an honor for you to serve as a member of my thesis committee. Your overall help and support in answering the many questions that I have had has been greatly appreciated.

Dr. Rob Rhykerd, thank you for serving as a member of my thesis committee and for your guidance inside and outside of the classroom. Thanks are extended to Kathy Scott and Mary Akers for all of their clerical assistance and for helping me with other questions in times of need.

Leo Brown, thank you for your help and assistance of everything you have done for me the past few years. The hours that you have spent to make sure everything was in 
order and ready when needed was very helpful in making everything fall together without any major issues.

T. D. K. 


\section{CONTENTS}

Page

ACKNOWLEDGMENTS $\quad$ i

CONTENTS iv

TABLES vi

CHAPTER

I. INTRODUCTION AND BACKGROUND 1

II. LITERATURE REVIEW 3

Grain Yield 3

Planting Population $\quad 5$

Light interception of the Canopy $\quad 6$

Seed Orientation 9

$\begin{array}{ll}\text { Silage Yield } & 10\end{array}$

Silage Composition $\quad 11$

Silage DM Yield 13

III. SEED ORIENTATION AND ROW DIRECTION ALTER

MAIZE GRAIN YIELD AND COMPOSITION 16

$\begin{array}{ll}\text { Abstract } & 16\end{array}$

Introduction $\quad 17$

$\begin{array}{lr}\text { Materials and Methods } & 18\end{array}$

Experiment $1 \quad 18$

Mechanics of Hand Planting 19

Grain Harvest 20

Experiment $2 \quad 20$

Grain Harvest 21

$\begin{array}{ll}\text { Statistical Analysis } & 21\end{array}$

$\begin{array}{ll}\text { Results and Discussion } & 22\end{array}$ 
Experiment $1 \quad 22$

Experiment 2

Conclusions 26

Implications $\quad 26$

Tables $\quad 28$

Literature Cited $\quad 34$

IV. IMPACT OF ORIENTATION OF PLANTED MAIZE SEEDS ON COMPOSITION AND FEEDING VALUE OF MAIZE PLANTS

$\begin{array}{ll}\text { Abstract } & 37\end{array}$

Introduction $\quad 38$

Materials and Methods $\quad 39$

Experiment $1 \quad 39$

Mechanics of Hand Planting $\quad 40$

Silage Harvest 41

Experiment 2

Silage Harvest $\quad 42$

Statistical Analysis $\quad 42$

Results and Discussion $\quad 43$

Experiment $1 \quad 43$

Experiment $2 \quad 45$

Conclusions $\quad 47$

Implications $\quad 47$

Tables $\quad 49$

Literature Cited $\quad 55$

V. SUMMARY AND SYNOPSIS

$\begin{array}{lr}\text { REFERENCES } & 59\end{array}$ 


\section{TABLES}

Table

1. Effects of row direction on grain yield and kernel composition in Trial 1

2. Effects of seed orientation on grain yield and kernel composition in Trial 1

3. Effects of plant population on grain yield and kernel composition in Trial 1

4. Effects of row direction on grain yield and kernel composition in Trial 2

5. Effects of seed orientation on grain yield and kernel composition in Trial 2

6. Effects of plant population on grain yield and kernel composition in Trial 2

7. Effects of seed orientation on silage yield and composition when harvested at approximately $33 \%$ DM in Trial 1

8. Effects of seed orientation on silage yield and composition when harvested at approximately $42 \%$ DM in Trial 1

9. Effects of seed orientation on silage yield and composition in Trial 2

10. Analysis of across row and randomly planted treatments analyzed within treatment using t-test comparisons in Trial 2 


\section{CHAPTER I}

\section{INTRODUCTION AND BACKGROUND}

Maize grain yields have increased from 54.7 bushels per acre in 1960 to 147 bushels per acre in 2011 (United States Department of Agriculture, 2012). Advances in seed genetics and plant health permitting planting densities to increase, and in machinery technology are responsible for these increases in yield. Other factors that may increase rate or efficiency of production would include orientation of kernels in the soil at planting, that can influence germination rate (Patten and Van Doren, 1970) and leaf orientation of plants within the canopy (Fortin and Pierce, 1996), and cardinal direction in which the row is planted, both of which can allow more light to penetrate into the canopy and reach leaves responsible for grain filling. (Karlen and Kasperbauer, 1989).

Spacing of plants within a rows can change the amount of light available to a plant; total plant yield can be increased when competition from neighboring plants is reduced (Nielson, 2001). As plant population is increased, the spacing between plants within a row is decreased. The close proximity of other plants will increase interplant competition. By controlling the direction of kernels at planting, direction of leaves can be manipulated in the canopy as the plant grows (Fortin and Pierce, 1996) and potentially decrease the degree of competition. Observations by Fortin and Pierce (1996) indicated that $60-74 \%$ of leaves at R1 grew parallel to the direction of the germ when orientation of 
the kernel at planting was controlled. However, leaves may be reoriented by the plants to capture more light when plants are competing for the same light source (Maddonni et al., 2002), but the degree that re-orientation of leaves can adjust for competition may be limited considering that the direction of incident light changes throughout the day within a field of maize.

Planted with their germ facing adjacent rows has increased yield of grain (Torres et al., 2010). In addition, planting seeds with their germ facing other rows also increased grain yields when compared with plants with germ directions being random. Presumably, these responses are attributable to differences in the amount of light that reaches lower leaves within the canopy. An increase in light penetration to lower leaves will increase both grain yield and weight of maize plants (Thomison and Geyer, 2009). To date, little research has been published regarding seed orientation and maize silage production. The amount of grain within maize silage relative to the total amount of plant dry matter will alter the concentration of energy within silage that is available for and digested by animals (NRC, 1996). The objectives of this Master's Thesis were to: determine the effects of seed orientation, row direction, and plant population on grain yield, grain composition, silage yield, and silage composition. 


\title{
CHAPTER II
}

\section{LITERATURE REVIEW}

\author{
Grain Yield
}

As the world population and living costs increase, maize producers continually strive to increase yields in order to increase their economic return. Maize grain yields have increased from 54.7 bushels per acre in 1960 to 147 bushels per acre in 2011 (United States Department of Agriculture, 2012). Improvements in seed genetics and technology have increased tolerance of maize plants to disease and inter-plant stresses. This permits plant density to increase, and those increases in plant density are largely responsible for these increases in grain yield. Orientation of the seed within the row, presumably through reducing inter-plant competition, also can influence the growth and development of the plant (Patten and Van Doren, 1970). Leaves adjacent to the ear appear largely responsible for providing sugars to the developing grain, so availability of light to reach these specific leaves is important for maximizing grain yield (Thomison and Geyer, 2009). Manipulating the cardinal direction in which the maize row is planted (Karlen and Kasperbauer, 1989) as well as the direction of each plant's leaves within the crop row (Fortin and Pierce, 1996), through affecting light penetration deeper into the canopy thereby might be expected to alter yield provided that other factors related to 
production (e.g., plant genetic potential, nutrient availability, weed competition, water availability) do not set a lower ceiling on plant growth or development.

Factors above and beyond technology and genetics can limit plant growth. Potential for maximum yield begins with maize plant emergence. Delayed emergence at the two leaf stages can decreases potential yield by as much as 4\% (Liu et al. 2004b), partly due to a decrease in the plant population and partly because delayed emergence may reflect greater divergence in time of emergence that will cause neighboring plants to differ in age. Plants that are older strongly compete for available nutrients and sunlight (Nafziger et al., 1991). These investigators planted adjacent rows on a single date or on different dates. At grain harvest plants within rows of uniform age had greater yields than rows of plants that differed in age. These findings agree with those of Liu et al. (2004c) who observed that delayed emergence decreased grain yield at a rate of $292.8 \mathrm{~kg} \mathrm{ha}^{-1}$ per day of delayed emergence in field-based planter trials.

Spacing of plants within a row will changes the degree of competition between neighboring plants that in turn can alter the amount of nutrients available to a plant. Uniform spacing between plants will increase yield due to reduced plant competition among closely spaced plants (Nielson, 2001). These workers evaluated within row plant spacing using a conventional planter with controlled seed disks that altered inter-plant spacing. Yield decreased at a rate of $106.7 \mathrm{~kg} \mathrm{ha}^{-1}$ per $2.54 \mathrm{~cm}$ increase in standard deviation of plant spacing. Supporting observations were reported by Liu et al. (2004c) who compared three different types of conventional maize planters where planter type (finger pick-up, air seeder, and vacuum meters) had different spacing of plants within a 
row. In contrast to these findings, Liu et al. (2004a) found no significant decrease in grain yield from increasing the within-row spacing of maize plants in hand planted plots. Presumably, inter-plant competition will be altered not only by spacing within a row but also by inter-row spacing and plant density within a row, e.g., total plant population.

\section{Plant Population}

As genetic technology in the seed industry increases, the ability of maize plants to thrive in higher stress conditions associated with plant population has increased (Tollenaar and Lee, 2002). Valentinuz and Tollenaar (2004) observed three eras of hybrids, 1950, 1980, and 1990. Newer genetic hybrids yielded1.9 times that of the older hybrid varieties. Newer hybrids had an increased leaf area and less leaf senescence during the grain filling period when compared with the older hybrids reflecting an improved plant health.

Water stress during the growing season can decrease grain yields (Porter et al. 1997) during the growing season. Porter et al. (1997) also observed maximum grain yield with plant populations between 82,000 and 89,000 plants $^{-1} \mathrm{a}^{-1}$ during a growing season when water supply was adequate. Similar to these findings, Van Roekel and Coulter (2012) observed row width, population, and hybrid interactions but yields were maximum at plant populations of 84,500 to 108,700 plants ha $^{-1}$. However, Thelen (2002) indicated that a population of 90,000 plants $\mathrm{ha}^{-1}$ had the highest grain yields than lower populations with no plateau being observed. These findings suggest that yield with 
modern hybrids can be increased beyond those normally used by using more dense planting populations if nutrients and water supply are adequate.

As planting populations increase, competition for resources among plants will increase. Porter et al. (1997) observed greater yields during a dry growing season when planting populations were decreased. When density of plants increases, stalk lodging will increase due to smaller stalk diameter (Widdecombe and Thelen, 2002). These researchers observed that the number of lodged stalks increased as plant population increased to 90,000 plants per ha ${ }^{-1}$. In an older study, Campbell (1964) observed that plants with ears had much weaker stalks compared to plants without ears, indicating either that transfer of nutrients from stalk to ear significantly weakened the stalk or that weight of the ear increased stress on the stalk causing it to fail.

Maize grain yield is the multiple of the number of fertilized developing kernels on the plant and weight per kernel (Duncan, 1975). The maximum number of kernels that a maize plant can produce is determined at or slightly after pollination; once pollination has occurred, the plant cannot produce more kernels (Duncan, 1975). As plant population increased, Maddoni et al. (2006) observed that yield and kernel numbers increased but weight of kernels decreased. Similar results were observed by Porter et al. (1997), who observed a decrease in kernel weight as population increased in field based experiments. Contrary to these findings, Widdecombe and Thelen (2002) observed slight increases in grain test weight as plant population increased.

Light Interception of the Canopy 
Light penetration into the canopy of maize plants is crucial to the production of a viable ear. Hashemi-Dezfouli and Herbert (1992) investigated how various plant densities altered light penetration into and through the canopy. They used plots with various shade treatments and plant populations to investigate the effects of decreased sunlight with different plant populations. As population increased, the number of barren stalks increased and kernels per ear decreased. These investigators also reported that shading of the plants delayed silk timing relative to tasseling that in turn reduced the number of kernels that were fertilized. Greater light interception by the leaves of plants during the grain filling periods was related positively to kernel weight (Maddonni et al. 2006).

When the sun moves across the sky during the day, the amount of light that penetrates into the canopy within a row of maize depends on the row direction. Eduardo et al. (2004) compared rows planted in north-south and east-west directions and examined the amount of green light $\left(\mathrm{r}_{550}\right)$ reflected by plant leaves. Plants grown in a north-south direction had higher reflectance throughout the day and were less dependent on the time of day than rows planted in east-west rows (Eduardo et al., 2004). Mohammad and Mohammad (2002) measured the amount of solar radiation that penetrated to varying depths into the canopy of plant leaves and measured input radiation. A difference in the degree of light penetration into the canopy was observed between maize rows planted in east-west versus north-south directions. Rows planted north-south tasseled significantly earlier and had higher grain yields presumably due to greater light interception at solar noon (Mohammad and Mohammad, 2002). Similar results were observed by Allen (1974) who measured solar radiation throughout the complete day 
using sorghum plants. He found the north-south orientation intercepted $44 \%$ of the solar radiation compared with 37\% for the east-west rows. Karlen and Kasperbauer (1989) observed that although row direction influenced light interception and grain yield, results from year to year were inconsistent perhaps due to changes in growing conditions. Over a two year period observations were made by these two investigators on plots of each row direction grown at approximately $34^{\circ} \mathrm{N}$. Drought stress was experienced during year one whereas rainfall was sufficient during year two. During the first year when drought stress was evident, the north-south orientation had increased yield, but in the second year when drought stress was absent, yields were similar for rows planted in both directions.

As the distance from the equator increases, the incident angle of sunlight changes and impact of row direction on light interception can change. Contrary to previous research Borger et al. (2010) in Australia observed that yield for wheat and barley plants was greater with rows in an east-west direction than in a north-south orientation. Borger et al. (2010) observed that the biomass of weeds was less with east-west rows and speculated that this was due to a lack of sunlight penetration to the soil surface that would hinder weed growth. Duncan (1975) observed that as planting population increased, the leaf area per plant did not decrease inversely. This indicates that the leaf area index of the canopy may be controlled by planting patterns and population density of plants.

Leaves at various locations of a maize plant differ in their importance for grain yield (Thomison and Geyer, 2009). These scientists removed leaves below the ear to evaluate the impacts of the leaves from the lower part of the canopy. When all leaves below the ear were removed, yield was decreased by only $19 \%$ indicating the leaves of 
the lower part of the canopy have some impact on grain yield. Duncan (1975) reported that lower leaves within the canopy will be lost if solar radiation is insufficient for maintenance of the leaf. Lack of soil fertility also can influence leaf senescence.

Leaves of growing maize plants sense the sunlight reaching the leaf. When far-red light hits the leaf surface, the plant attempts to rotate its leaves around the stalk to receive full sunlight (Maddonni et al. 2002). These researchers observed that some hybrids had greater ability to rotate leaf direction than other hybrids when a light obstruction was placed near leaves. Another feature of the maize plants' leaf is that as leaves become stressed due to a lack of water, the leaves roll to cover stomata on the leafs' top surface (Duncan, 1975). Also, plants can rotate leaves in low moisture environments to conserve moisture through avoiding direct solar radiation and will position leaves under the shade of the upper canopy (Fortin and Pierce, 1996). Leaf direction within row also may reflect water stress as plants attempt to conserve moisture through avoiding direct solar radiation (Fortin and Pierce, 1996). These researchers observed an increase in the number of leaves that were positioned parallel to the row in dry growing conditions. Presence of leaves parallel to a row may reflect insufficient moisture as growing plants rotate their leaves away from direct sunlight.

\section{Seed Orientation}

Altering the direction and position of seed placement in the soil can influence germination rate and direction of the leaves within rows (Patten and Van Doren, 1970). When placed tip down in the soil, seeds have a greater germination rate and time for 
emergence is decreased. Patten and Van Doren (1970) reported that germination occurred three to five days earlier and emerged $12 \%$ sooner for seeds planted tip down compared to seeds planted tip up. Leaves of maize plants emerge from the germ side of the kernel so the initial leaves are located perpendicular germ of the kernel for kernels planted tip down irrespective of the row direction (Fortin and Pierce, 1996). Fortin and Pierce (1996) observed when seed placement was controlled, 60 to $74 \%$ of leaves were within $45^{\circ}$ degrees of the predicted direction of the germ. In contrast, when seeds were planted randomly, leaves were arranged randomly within the canopy. The ability of leaves to change their orientation could speed closure of the canopy earlier allowing plants to intercept light more quickly (Fortin and Pierce, 1996).

When the direction of the leaves is controlled, the fraction of incident light interception captured by plants can be increased allowing grain yield to be increased (Toler et al. 1999). Toler et al. (1999) observed when maize had leaves perpendicular to the row in the field, grain yield was increased by $10 \%$ over having leaves arranged randomly by over $25 \%$ over having leaves parallel to the row of maize in the field. Though the leaves emerge first can be manipulated by controlled planting methods, other factors also can influence the direction of leaves within the row as plants grow (Maddonni et al., 2002; Fortin and Pierce, 1996). When plant population was increased and competition for light among plants in a row increased, Girardin and Tollenaar (1994) observed that more of the plants reoriented their leaves perpendicular to the row. As plant population increases, the distance between plants within a row decreases, and when 
plants are closer together, the leaves tend to orientate their leaves perpendicular to the row to intercept more light (Girardin and Tollennaar, 1994; Maddonni et al., 2002).

\section{Silage Yield}

Silage yields from maize will increase as plant population increases provided the supply of water and other nutrients is adequate. The population needed to maximize silage dry matter yield is greater than the population needed to maximize grain yield, at least for older hybrids (Rutger and Crowder, 1967a). When evaluating dry matter (DM) production, Rutger and Crowder, (1967b) observed that a plant population of 88,000 plants ha ${ }^{-1}$ maximized grain DM yield, but total DM yield was greater with a plant population of 125,000 plants $\mathrm{ha}^{-1}$. Millner et al. (2005) observed increasing planting population from 75,000 to 100,000 plants $^{-1} \mathrm{~s}^{-1}$ significantly increased total DM yield, but raising population to 140,000 plants $\mathrm{ha}^{-1}$ did not increase DM yield further. Similar results were observed by Graybill et al. (1991) over a two year trial in which DM yield was maximized at 80,000 plants $\mathrm{ha}^{-1}$ for multiple hybrids. Cusicanqui and Lauer (1999) observed that as plant population is increased, DM yield begins to plateau when density exceeds 75,300 plants ha ${ }^{-1}$.

Timing of maize harvest relative to plant maturity can impact the quality, yield and DM content of plants harvested for silage. Acceptable ensiling moisture for silage to ferment properly is between 30 to $40 \%$ DM content (Wiersma et al., 1993). Maximum DM yield of maize harvested for silage has been reported to occur between 30 to $40 \%$ DM content based on studies 4 decades ago (Cummins, 1970; Caldwell and Perry, 1971). 
As plants mature further, DM yield begins to decrease. However, more recent studies by Darby and Lauer (2002) observed that DM yield reached a maximum at $42 \%$ plant DM, higher than previous research perhaps related to the improved late-season plant health of modern hybrids.

\section{Silage Composition}

Maize silage is comprised of the vegetative (stover) portion of the plant plus the ear that carries the grain. At a plant DM content of about $30 \%$ the vegetative portion of the plant and NDF yield per plant has reached its maximum. Above $30 \%$ plant DM, the increase in DM content is all due to growth and development of the ear and grain. The amount of grain in silage in turn alters the amount of crude protein and energy (primarily starch) present in the silage to provide energy and protein for livestock. When plants are harvested in the absence of ears (stover), the total digestible nutrients (TDN) as a percentage is about 55\%; when harvested after the ears are fully developed, TDN can reach $70 \%$ (NRC, 1996). This increase in TDN reflects the greater energy content of the ear than the stover. Coors et al. (1997) observed that as grain content of plants increased, crude protein $(\mathrm{CP})$ often decreased even though digestibility increased. In contrast, Millner et al. (2005) observed no significant effect of hybrid effect on CP content of the biomass among seven hybrids. Each had a CP content between 6.6 and 7.25\% of DM. Cusicanqui and Lauer (1999) observed that CP decreased by $12 \mathrm{~g} \mathrm{~kg}^{-1}$ for each plant population increase of 1000 plant ha $^{-1}$. Millner et al. (2005) observed that as population increased, the ratio of ear to leaf plus stem decreased even though DM yield increased. 
The two components that make up silage, the stover and the ear, determine the nutrient composition of the feedstuff because these plant parts differ in energy and crude protein content (Millner et al., 2005). Grain has the highest level of metabolizable energy, followed by cob, leaf, and stem. Millner et al. (2005) observed that digestible energy content paralleled biomass yield of various hybrids. This presumably reflects the fact that as plants mature and ears develop and grow, the ear is adding both biomass and starch to the plant. Across 6 hybrids, relative to the leaves, the stalk and cob components were more variable in energy content.

\section{Silage DM yield}

Both DM content and DM yield increase as the maize plant matures. In contrast, CP as a percentage of DM will decrease linearly (Darby and Lauer, 2002; Wiersma et al., 1993). As plant population is maize increased, the percentage of grain in silage decreases (Rutger and Crowder, 1967a; Millner et al., 2005). Rutger and Crowder (1967a) observed as plant population increased from 50,000 to 80,000 plants $^{-1}$ grain content decreased from $42.9 \%$ to $39.2 \%$. Millner et al. (2005) evaluated seven hybrids for grain concentration and observed that grain was $50.7 \%$ of DM for the hybrid with the lowest DM yield but $41.2 \%$ of DM for the hybrid with the greatest DM yield. Within a hybrid, grain yield does not increase as rapidly as DM yield when plant population is increased again illustrating that the ratio of grain to stover decreases as plant population is increased (Rutger and Crowder, 1967a). Similarly, Millner et al. (2005) observed that as DM yield increased, the percent leaf and stem increased relative to cob and grain concentrations. Campbell (1964) investigated the effects of absence of ears and found 
plants without ears accumulated significantly more stalk dry matter than those plants which had ears. The higher stalk and leaf DM yield of plants without ears is believed to be due to an excess of carbohydrates from the plant which are not needed to produce grain when the plant matures (Campbell, 1964).

Carbohydrates within a corn plant are translocated as the plant matures from its vegetative growth stages to its reproductive stage and grain is produced. As plants mature, structural carbohydrates appear to be mobilized and transferred from the stalk to the grain and deposited as non-structural carbohydrates within (Albrecht et al. 1986). Duncan (1975) observed that stalk weight increased until plants tasseled; thereafter, stalk weight decreased until grain harvest presumably due to the transfer of nutrients to the developing kernels. Duncan (1970) observed that plants with stronger stalks were less digestible than plants with weaker stalks when harvested early reflecting the degree that carbohydrates present were structural. Colbert et al. (1984) compared hybrids that differed in stalk strength and found that the amount of soluble solids within the stalk was positively correlated to stalk strength. Campbell (1964) measured the concentration of soluble solids of plants without ears with those of plants with ears. Values were $15-17 \%$ and $8-10 \%$, respectively. Total available carbohydrate contents can be used as an estimate of quality of a feed or forage. For silage, a DM content of $37 \%$ was observed to be the point that maximized total available carbohydrates content of maize silage (Cummins, 1970). This researcher indicated that the availability of carbohydrates during maize maturation is correlated with rainfall with late season rain increasing the quantity of available carbohydrates. 
Height above the soil at which the plant is harvested will alter both yield of DM and composition of that DM. When harvest height is raised, stover digestibility increases because neutral detergent fiber (NDF) concentration is reduced (Lewis et al., 2004). This reflects the fact that NDF content of plants is higher for the lower than the higher section of the stalk and leaves from the lower portion of the stalk, that are lower in NDF than stalk, often are lost prior to harvest. Chopping the plant at a greater height reduces the yield dry matter, but often increases the quality of the silage. Neutral detergent fiber content of maize plants decrease in concentration as plants mature and harvest is delayed (Darby and Lauer, 2002; Wiersma et al., 1993) reflecting dilution by an increased proportion of grain. However, lignification of cell walls also increases decreasing the digestibility of NDF of the silage (Darby and Lauer, 2002). These researchers observed a decrease in digestibility of cell walls (NDF) after R1 up to the last harvest date. Lignification of cell walls was suggested as being the cause of the decline in digestibility though mobilization of structural carbohydrates of the stalk during grain deposition leaving only the less digestible NDF behind also could explain this decline. Indeed, the amount of indigestible NDF remained constant for maize plants harvested at various maturities in studies by Cox and by Lewis because the grams of NDF per plant decreased as NDF digestibility decreased. Consequently, any change in NDF digestibility must consider changes in NDF content to appraise its impact on total tract digestibility of a feed or forage. 


\title{
CHAPTER III
}

\section{SEED ORIENTATION AND ROW DIRECTION ALTER MAIZE GRAIN YIELD AND COMPOSITION}

\begin{abstract}
Through altering interplant shading, compass direction of maize rows may alter grain yield. In addition, through altering early leaf direction, orientation of planted seeds may alter interplant shading. Impacts of row direction and seed orientation were studied in central Illinois in two experiments. In experiment 1, two Pioneer maize silage hybrids were planted in plots 12 rows wide (rows $76 \mathrm{~cm}$ apart) at $69 \mathrm{~K}$ and $84 \mathrm{~K}$ plants/hectare. Seeds were planted either randomly (with a mechanical maize planter) or manually with all kernel tips downward but with the kernel germ facing either plants within the same row or toward plants in adjacent rows. Randomly planted kernels were grown in both North-South (NS) and East-West (EW) rows. Based on weight of shelled grain at maturity, grain yields were greater $(\mathrm{P}<0.05)$ for kernels planted with their germ facing adjacent rows than facing their own row, and both manually planted orientations were greater than for mechanically planted grain (13.0 vs. 11.9 and 10.9 metric tons/ha; $\mathrm{P} \leq$ 0.05) due to lighter kernel weight and fewer kernels per ear for randomly planted seeds. Grain yields were $26 \%$ greater $(\mathrm{P} \leq 0.01)$ for NS rows due to heavier kernels and more kernels per ear $(\mathrm{P} \leq 0.01)$. In experiment 2 , three Pioneer hybrids were grown with three seed orientations in both EW and NS rows. Yields again were least $(\mathrm{P}<0.05)$ for kernels
\end{abstract}


planted randomly $(12.2,12.1$, and 10.5 metric tons/ha for across, intra, and randomly oriented germs). Randomly planted kernels had the lowest kernel density but the highest percentage of starch. Grain yields again were greater for NS rows (12.0 vs. 11.6 metric tons/ha; $\mathrm{P} \leq 0.01)$ due to $6.5 \%$ greater kernel weights $(\mathrm{P} \leq 0.01)$. The higher plant population increased grain yield per hectare but decreased kernels per ear $(\mathrm{P}<0.02)$. Regressed across all samples, each $1 \%$ added starch displaced $0.38 \%$ oil and $0.44 \%$ protein. Grain yields were greater for kernels specifically at planting and when grown in NS than in EW rows.

Keywords: Maize grain, row direction, yield

\section{Introduction}

Within the United States, maize grain yields have increased from 55 bushels acre $^{-1}$ in 1960 to 147 bushels acre ${ }^{-1}$ in 2011 (USDA, 2012). This increase in yield of maize grain can be attributed to improved genetics of the hybrids being marketed and to increased technology that has improved the uniformity of spacing of plants within rows and rows within fields. Much of the increase in yield has been achieved from an increase in the plant population (plants per hectare) thanks to selection of hybrids for greater tolerance of plants to the biotic and abiotic stresses associated with higher plant populations and (Tollenaar and Lee, 2002). Compared with older hybrids, those developed more recently have an increased leaf area per plant and decreased leaf senescence and susceptibility to plant diseases during grain filling period (Valentinuz and Tollenaar, 2004). Uniform spacing of plants and more upright positioning of leaves has 
helped to reduce interplant competition and to increase the quantity of incident light that reaches deep into the canopy to the leaves responsible for grain filling (Nielson, 2001). The quantity of light that penetrates into the canopy in turn depends on orientation of the plant leaves within a row and by the direction in which the rows are planted. The impact of the cardinal direction in which rows are planted was studied by (Karlen and Kasperbauer, 1989) while leaf direction, as altered by the orientation that maize kernels are planted into the soil was studied by (Fortin and Pierce, 1996).

This study was designed to 1) test the degree to which controlling the orientation of maize kernels in the soil would alter the orientation of plant leaves and orientation and 2) test the impacts on yields of plant and grain DM the special orientation of the kernels being planted. To control seed orientation, kernels were planted manually for comparison with kernels planted with a conventional maize planter for which seeds were considered to be planted with a random orientation. Grain yields were measured and kernels from each orientation assayed for density and nutrient composition (starch, oil, and protein content).

Materials and methods

\section{Experiment 1}

During the 2011 growing season two Pioneer maize silage hybrids were grown in plots within a field where kernels were either planted manually in specific orientations or planted with a conventional maize planter. Rows ran in an east-west direction. Plots were $4.7 \mathrm{~m}$ long by $9.12 \mathrm{~m}$ wide (12 rows wide with a 0.76 - $\mathrm{m}$ intra-row spacing) within a 
single field at the Illinois State University research farm in Lexington, IL. Individual plots consisted of six rows of a single hybrid at a single plant population where kernels were hand planted in one of two directions with the germ either facing adjacent rows or facing plants within the row or planted randomly with a conventional maize planter. Each treatment was replicated and planted to achieve either a lower plant population $(69,000$ plants ha $\left.{ }^{-1}\right)$ or a higher plant population $\left(84,000\right.$ plants $\left.a^{-1}\right)$. A John Deere 7000 (Moline, IL) conventional maize planter was used to achieve a random seed placement in the soil. Randomly planted rows were grown adjacent to hand rows at the same populations and also were replicated within rows in a north south direction adjacent to hand planted plots.

\section{Mechanics of Hand Planting}

To achieve specific orientations of kernels being planted, individual kernels were loaded into straws that in turn were spacially oriented within planting jigs that controlled both plant spacing and seed orientation within the plant row. First, individual kernels were placed in soda straws that were $21 \mathrm{~cm}$ long with a $0.7 \mathrm{~cm}$ internal diameter. Each straw had a red line on one side of the straw. The germ of each kernel was aligned with this red line of each straw. Kernels of each hybrid were loaded into straws at least 4 weeks prior to being planted. For planting, 16 wooden jigs $117.5 \mathrm{~cm}$ in length and $16 \mathrm{~cm}$ in height were constructed. Eight of these jigs had holes spaced at $18.97-\mathrm{cm}$ whereas eight had holes spaced at $15.62-\mathrm{cm}$ so that kernels being planted had plant populations of 69,000 plants ha ${ }^{-1}$ and 84,000 plants ha ${ }^{-1}$, respectively. Once the boards were laid on the soil at the proper location within the desired row, each straw was placed into a hole in the 
jig until the top of the straw was aligned with the top jig (so that the tip of the straw was 5 $\mathrm{cm}$ below the surface of the soil). The red line on each straw was aligned with a red mark on the jig so that the germ of each kernel was oriented in the desired direction. Finally, a wooden dowel the same length as the straws was pushed into each straw as a plunger to plant each seed into the soil without altering the orientation of the kernel. The red marks on four of the jigs were parallel with the length of the jig so that the germ of adjacent plants all faced the same direction and faced other seeds within the row. The other two jigs had red lines that alternately faced adjacent rows so that germs all faced kernels in adjacent rows but in an alternating fashion.

\section{Grain Harvest}

Replicate sets of five randomly selected ears were harvested plants from the center two rows of set of 6 rows with a specific seed orientation, hybrid, and plant population. Shucks were removed weight of undried whole ears was determined using a digital scale. Grain was shelled using a John Deere model 1B (Moline, IL) hand crank maize sheller and weighed to obtain clean grain weight. Following weighing, grain samples were collected for further analysis. Grain was partially dried (15\% moisture) and weight again was measured. These grain samples were assayed intact by near infra-red (NIR) procedures standardized by DuPont Pioneer (Johnston, Iowa) for starch, soluble sugars, crude protein, residual dry matter, and ash. In addition, grain was assayed for density by a gas displacement pycnometer, bushel weight using a Dickey John Grain Analyzer, and weight of 100 kernels was measured. 


\section{Experiment 2}

During the 2012 growing season three Pioneer maize silage hybrids were grown in hand planted plots and in mechanically planted plots measuring $4.7 \mathrm{~m}$ long by $9.12 \mathrm{~m}$ wide (12 rows wide in $0.76-\mathrm{m}$ row spacing) at the Illinois State University research farm in Normal, IL. Six rows of each plot were hand planted by the method described for

experiment 1. Each treatment was replicated at a low population of 69,000 plants $^{-1}$ and at a high population of 84,000 plants ha ${ }^{-1}$. A conventional John Deere 7000 (Moline, IL) maize planter was for seed placement assumed to be random in rows adjacent to hand planted rows. All treatments were replicated in north-south and east-west rows.

\section{Grain Harvest}

Two sets of five randomly selected ears were harvested from the center two rows of each treatment. After shucks were removed, wet weight of each whole ear was determined. Grain from the combination of ears was shelled using a John Deere model 1B (Moline, IL) hand crank maize sheller and weighed to obtain clean wet grain weight. Following weighing, grain samples were collected for further analysis. Grain was partially dried (10 to $15 \%$ moisture) and weight loss measured. Once dried, grain was assayed intact by NIR procedures standardized by DuPont Pioneer (Johnston, Iowa) for starch, soluble sugars, crude protein, residual dry matter, and ash. In addition, grain was assayed for density by a gas displacement pycnometer, bushel weight using a Dickey John Grain Analyzer (Auburn, Illinois), and weight of 100 kernels was measured.

\section{Statistical Analysis}


Analysis of variance for a fixed factorial was used for experiment 1 using SAS version 9.2 (SAS Inst., Carry NC). All treatment factors in the experiment were considered fixed effects. Randomly planted rows in the NS row orientation were compared to EW randomly planted rows separately from the hand planted treatments in experiment 1 . In experiment 2 all factors were considered to be fixed effects with all treatments compared as a single factorial experiment. Orthogonal contrasts were employed to separate the effect of kernel tip orientation from the effect of germ direction. For testing the kernel tip effect, the response to random planted kernels was compared with the response to germ oriented kernels. For testing the germ direction effect, the response to kernels with germs facing other rows was compared to response to kernels with germs facing other plants within the same row.

\section{Results and Discussion}

\section{Experiment 1}

Grain yield was $27 \%$ greater $(P \leq 0.0001)$ for randomly planted maize in NS rows compared to randomly planted EW rows. Kernel weights were greater $(P \leq 0.0001)$ and ears had more kernels $(P=0.0016)$ for NS rows compared to EW rows (Table 1$)$ which can explain the increase in grain yield. Other researchers (Karlen and Kasperbauer, 1989; Crasta and Dixit 1980; Grewal, 1989; Akbar and Khan, 2002) previously also have observed increased grain yields for maize planted in NS rows compared to EW rows. The oil content and density were greater for kernels planted in NS rows greater than for 
kernels planted in EW rows (Table 1). Protein and starch were not significantly altered $(\mathrm{P}=0.77, P=0.5615$, respectively) by row direction (Table 1$)$.

Within the hand planted plots where seed orientation was measured for EW rows, (Table 2), grain yield was significantly greater for grain from rows where kernels had been planted tip down than for kernels whose tips had been random. Increases in both kernel weight $(P=0.0003)$ and kernels per ear $(P=.0509)$ were detected for rows with orientated kernels (Table2) and these match with the increased grain yield. Toler et al. (1999) observed increased yields from rows of plants with kernels planted with germs facing adjacent rows than for rows of plants with kernels planted randomly and attributed this to faster canopy closure and increased light interception of plants. Toler et al. (1999) also observed that randomly planted kernels had greater leaf area that would increase light absorption. Their results agree numerically with observations of this study though their increases in yield were significant $(P=0.0009)$ with seed orientation across rows compared to their randomly planted kernels. Maddonni et al. (2006) attributed an increased kernel weight with seeds planted with an across row orientation to an acrossrow orientation of plant leaves that increased light interception during the grain filling period.

Hand planted treatments were compared to randomly planted kernels to observe differences from kernels planted tip down in the soil compared to random seed placement. Kernels that were planted tip down increased grain yield 14\% $(P=0.0395)$ compared to randomly planted kernels. Kernel weight was $5 \%$ greater $(P=0.0093)$ for kernels planted tip down; kernels per ear also were numerically greater for kernels 
planted tip down (Table 2). When two hand planted treatments were compared, the across row germ orientation increased grain yield by $9 \%(P=0.0395)$ compared to with row germ orientation. All other factors that were measured did not significantly differ between germ orientations (Table 2).

When plant population was increased from 69,000 to 84,000 plants $^{-1}$, grain yield increased $(P<0.0001)$ by $34 \%$. This increase in grain yield from the higher plant population can be attributed to significantly greater number of kernels per ear for plants planted at 84,000 plants ha ${ }^{-1}$ (Table 3). Porter et al. (1997) observed similar results where grain yield was maximized at population treatments between 82,000 and 89,000 plants $\mathrm{ha}^{-1}$. In the study reported here, kernel weight was observed to be numerically greater for the high plant population (Table 3). In contrast, kernel density and protein content of the kernels were significantly greater when the low plant population was lower (Table 3). Widecombe and Thelen, (2002) observed similar results, as plant population increased kernel weight also increased. However, Porter et al. (1997) observed that test weight decreased as plant population increased.

\section{Experiment 2}

When combined across all seed orientations and plant populations, grain yield from plants in NS rows was $3 \%$ greater $(P \leq 0.0001)$ than for plants in EW rows. This increased grain yield can be attributed to a 7\% $(P=0.005)$ increase in kernel weight from NS compared to EW rows. These results with increased grain yield from NS rows match those from Exp 1. Density, oil content, protein and starch content of the kernels were not 
significantly altered $(P=0.6362, P=0.5213, P=0.9037, P=0.8759$, respectively) by row direction (Table 4). Grain yield similarly did not alter kernel composition in a report from Bullock et al. (1989).

Both seed orientation treatments had significantly greater grain yields compared to randomly planted kernels (Table 5). Grain yields were numerically greater for seeds planted with an across row than a within-row orientation. . Results of the current study are supported by Torres et al. (2010) who observed a greater yield with seeds planted in an across row orientation compared to randomly planted kernels. However, Torres et al. (2010) observed that randomly planted kernels had greater grain yield than plants whose leaves were orientated with the row, opposite the observations of the study reported here. Kernel weights for rows with seeds specifically oriented were numerically greater than for than for rows of seeds that were planted randomly (Table 5). However, starch content was significantly greater for kernels from randomly planted seeds than from seeds oriented either across rows or within rows (Table 5). Grain for randomly planted kernels had lower oil and protein content than grain from plants with oriented seeds (Table 5). These compositional changes match those reported Armstrong and Tallada (2012) who observed that as kernel starch increased, kernel oil and kernel protein content decreased.

Hand planted treatments were compared to randomly planted kernels to observe differences from kernels planted tip down in the soil compared to random seed placement. Kernels that were planted tip down had $12 \%$ greater $(P=<0.0001)$ grain yield compared to randomly planted kernels. Density was increased for kernels planted tip down $(P=0.0156)$ compared to kernels randomly planted. When two hand planted 
treatments were compared, the across row germ orientation resulted in a numerically increased grain yield compared to the within row germ orientation. None of the factors related to germ orientation were significantly different (Table 5).

Grain yield was greater $(P<0.0001)$ with the higher than the lower plant populations (Table 6). Kernels per ear were significantly lower with the higher than the lower plant population (Table 6) and kernel weights were numerically greater for low plant population (Table 6), but the higher number of plants per acre more than compensated for these decreased in number of kernels per ear and kernel weights. Porter et al. (1997) observed similar results in dry growing seasons where increased competition for water and nutrients decreased per plant yield of higher plant populations. Density, oil content, protein and starch concentrations in the kernels were not affected by plant population treatments (Table 6).

\section{Conclusions}

Results of this study support the original hypothesis that orientating seeds being planted can orient the plant leaves and increase grain yield. Grain yields of plants also were greater for plants grown in NS rows than for plants grown in EW rows. Kernel weights from grain for NS rows were greater than kernel weights of grain from EW rows. When plant population was increased, regardless of seed orientation, grain yield was increased. Kernels from plants whose seeds were specifically oriented had lower kernel density and less kernel starch content than kernels from plants whose seeds were planted 
at random. Across all grain samples for each $1 \%$ increase in starch content, oil decreased by $0.38 \%$ and protein decreased by $0.44 \%$.

\section{Implications}

Through manipulation of row direction and seed orientation, grain yield and kernel composition can be altered. Grain yield was greater when interplant competition was reduced presumably because an altered leaf orientation allowed sunlight to penetrate deeper into the canopy to contact the ear leaves that play the most vital role in grain filling. Although planting rows in a NS direction increased grain yields, row direction can be limited by field shape and topography. Further testing and application of orientation of planting maize seeds currently is limited by planter technology. Currently, maize planters do not plant kernels with a specified orientation because kernels are metered above the soil surface and fall into the soil randomly. If further research verifies the increased grain yield associated with specifically orienting seeds being planted under a wide variety of geographic conditions, engineers will incorporate technologies to planters that can orient seeds in a specific fashion. 
TABLES FOR CHAPTER III: SEED ORIENTATION AND ROW DIRECTION ALTER MAIZE GRAIN YIELD AND COMPOSITION

Table 1. Effects of row direction on grain yield and kernel composition in Trial 1

\begin{tabular}{lccc}
\hline \hline \multirow{2}{*}{\multicolumn{1}{c}{ Variable }} & \multicolumn{2}{c}{ Row Direction } & \\
\cline { 2 - 4 } & North to South & East toWest & -value \\
\hline Grain Yield, metric tons & $13.7^{\mathrm{a}}$ & 10.8 & TRT \\
ha $^{-1}$ & 540.0 & $485.6^{\mathrm{a}}$ & $<0.0001$ \\
Kernels per ear & $37.54^{\mathrm{a}}$ & 33.10 & 0.0016 \\
Weight of 100 kernels, g & 1.3039 & 1.2988 & $<0.0001$ \\
Density, g/ml & $2.90^{\mathrm{a}}$ & 2.69 & 0.1002 \\
Oil content, \% & 9.70 & 9.68 & 0.0003 \\
Protein, \% & 71.70 & 71.77 & 0.77 \\
Starch, \% & & & 0.5615 \\
\hline
\end{tabular}

${ }^{a b c}$ Means within a row with different superscripts differ significantly $(P<0.05)$.

${ }^{1}$ Row direction: North to South $=$ Cardinal direction rows are planted, East to West $=$ Cardinal direction rows are planted

${ }^{2} P$-value: TRT=Main effect of treatment 
Table 2. Effects of seed orientation on grain yield and kernel composition in Trial 1

\begin{tabular}{|c|c|c|c|c|c|c|}
\hline \multirow[b]{2}{*}{ Variable } & \multicolumn{3}{|c|}{ Seed orientation $^{1}$} & \multirow{2}{*}{$\begin{array}{c}P \text {-value }{ }^{2} \\
\text { TRT }\end{array}$} & \multirow{2}{*}{$\begin{array}{c}P \text {-value } \\
\text { Tip Down }\end{array}$} & \multirow{2}{*}{$\begin{array}{c}P \text {-value } \\
\text { Germ }\end{array}$} \\
\hline & Across-row & With-row & Random & & & \\
\hline Grain Yield, metric tons ha ${ }^{-1}$ & $13.0^{\mathrm{a}}$ & $11.9^{\mathrm{b}}$ & 10.9 & 0.0009 & 0.0014 & 0.0395 \\
\hline Kernels per ear & $535.62^{a}$ & 501.71 & 485.64 & 0.0509 & 0.0664 & 0.1016 \\
\hline Weight of 100 kernels, $g$ & 35.08 & 34.43 & $33.01^{\mathrm{a}}$ & 0.0003 & 0.0093 & 0.4656 \\
\hline Density, g/ml & 1.3017 & 1.2991 & 1.2988 & 0.2293 & 0.6927 & 0.5776 \\
\hline Oil content, $\%$ & 2.78 & 2.76 & 2.69 & 0.3569 & 0.5727 & 0.9397 \\
\hline Protein, $\%$ & 9.53 & 9.64 & $9.69^{\mathrm{a}}$ & 0.1211 & 0.5461 & 0.5795 \\
\hline Starch, \% & $72.06^{\mathrm{a}}$ & 71.68 & 71.78 & 0.0446 & 0.7868 & 0.3404 \\
\hline
\end{tabular}

${ }^{\text {abc }}$ Means within a row with different superscripts differ significantly $(P<0.05)$.

${ }^{1}$ Seed orientation: Across-row= Kernel planted with germ facing adjacent row; With-row=Kernel planted with germ facing adjacent kernels in same row, Random= Kernel planted with conventional planter.

${ }^{2} P$-value: TRT=Main effect of treatment

3 P-value: Tip down= Average of Across row and With row planted tip down compared to Randomly planted

4 P-value: Germ=Across row compared to With row controlled orientation of germ 
Table 3. Effects of plant population on grain yield and kernel composition in Trial 1

\begin{tabular}{lccc}
\hline \hline \multirow{1}{*}{\multicolumn{1}{c}{ Variable }} & \multicolumn{2}{c}{ Plants per hectare } & $P$-value \\
\cline { 2 - 4 } & 69,000 & 84,000 & TRT \\
\hline Grain Yield, metric tons & 10.2 & $13.7^{\mathrm{a}}$ & $<0.0001$ \\
ha $^{-1}$ & 484.24 & $531.1^{\mathrm{a}}$ & 0.0066 \\
Kernels per ear & 34.12 & 34.29 & 0.8065 \\
Weight of 100 kernels, g & $1.3053^{\mathrm{a}}$ & 1.2945 & 0.0002 \\
Density, g/ml & 2.69 & 2.79 & 0.0651 \\
Oil content, \% & $9.81^{\mathrm{a}}$ & 9.43 & $<0.0001$ \\
Protein, \% & 71.95 & 71.71 & 0.0651 \\
Starch, \% & & & \\
\hline
\end{tabular}

${ }^{a b c}$ Means within a row with different superscripts differ significantly $(P<0.05)$.

${ }^{1} P$-value: TRT=Main effect of treatment 
Table 4. Effects of row direction on grain yield and kernel composition in Trial 2

\begin{tabular}{lccc}
\hline \hline \multirow{2}{*}{\multicolumn{1}{c}{ Variable }} & \multicolumn{2}{c}{ Row Direction $^{1}$} & $P$-value \\
\cline { 2 - 4 } & North to South & East to West & TRT \\
\hline Grain Yield, metric tons & $12.0^{\mathrm{a}}$ & 11.6 & $<0.0001$ \\
ha $^{-1}$ & $34.29^{\mathrm{a}}$ & 32.19 & 0.0054 \\
Weight of 100 kernels, g & 1.2753 & 1.2772 & 0.6362 \\
Density, g/ml & 3.53 & 3.49 & 0.5213 \\
Oil content, \% & 8.92 & 8.93 & 0.9037 \\
Protein, \% & 70.25 & 70.27 & 0.8759 \\
Starch, \% & & & \\
\hline
\end{tabular}

${ }^{\mathrm{abc}}$ Means within a row with different superscripts differ significantly $(P<0.05)$.

${ }^{1}$ Row direction: North to South $=$ Cardinal direction rows are planted, East to West $=$ Cardinal direction rows are planted

${ }^{2} P$-value: $T R T=$ Main effect of treatment 
Table 5. Effects of seed orientation on grain yield and kernel composition in Trial 2

\begin{tabular}{|c|c|c|c|c|c|c|}
\hline \multirow[t]{2}{*}{ Variable } & \multicolumn{3}{|c|}{ Seed orientation } & $P$-value ${ }^{2}$ & $P$-value ${ }^{3}$ & $P$-value ${ }^{4}$ \\
\hline & Across-row & With-row & Random & TRT & Tip down & Germ \\
\hline Grain Yield, metric tons ha $^{-1}$ & 12.0 & 11.6 & $10.5^{\mathrm{a}}$ & $<0.0001$ & $<0.0001$ & 0.6223 \\
\hline Weight of 100 kernels, g & 33.06 & 33.70 & 32.97 & 0.6669 & 0.5936 & 0.4706 \\
\hline Density, $\mathrm{g} / \mathrm{ml}$ & 1.2790 & 1.2805 & $1.2691^{\mathrm{a}}$ & 0.0499 & 0.0156 & 0.7759 \\
\hline Oil content, $\%$ & 3.51 & 3.59 & $3.41^{\mathrm{a}}$ & 0.047 & 0.1220 & 0.2684 \\
\hline Protein, $\%$ & 9.00 & 8.99 & $8.78^{\mathrm{a}}$ & 0.0163 & 0.1747 & 0.6383 \\
\hline Starch, \% & 70.23 & 70.10 & $70.46^{\mathrm{a}}$ & 0.0224 & 0.7208 & 0.4999 \\
\hline
\end{tabular}

${ }^{\mathrm{abc}}$ Means within a row with different superscripts differ significantly $(P<0.05)$.

${ }^{1}$ Seed orientation: Across-row= Kernel planted with germ facing adjacent row; With-row=Kernel planted with germ facing adjacent kernels in same row, Random $=$ Kernel planted with conventional planter.

${ }^{2} P$-value: TRT=Main effect of treatment

${ }^{3} P$-value: Tip down $=$ Average of Across row and With row planted tip down compared to Randomly planted

${ }^{4} P$-value: Germ=Across row compared to With row controlled orientation of germ 
Table 6. Effects of plant population on grain yield and kernel composition in Trial 2

\begin{tabular}{lccc}
\hline \hline \multirow{2}{*}{ Variable } & \multicolumn{2}{c}{ Plants per hectare } & $P$-value \\
\cline { 2 - 4 } & 69,000 & 84,000 & TRT \\
\hline Grain Yield, metric tons & 11.1 & $12.0^{\mathrm{a}}$ & $<.0001$ \\
ha $^{-1}$ & $480.06^{\mathrm{a}}$ & 433.16 & $<0.02$ \\
Kernels per ear & 33.51 & 32.98 & 0.4662 \\
Weight of 100 kernels, g & 1.2760 & 1.2763 & 0.9508 \\
Density, g/ml & 3.50 & 3.51 & 0.8544 \\
Oil content, \% & 8.96 & 8.88 & 0.2453 \\
Protein, \% & 70.25 & 70.27 & 0.8350 \\
Starch, \% &
\end{tabular}

${ }^{\mathrm{abc}}$ Means within a row with different superscripts differ significantly $(P<0.05)$.

${ }^{1} P$-value: TRT=Main effect of treatment 


\section{Literature Cited}

Armstrong, P., and Tallada, J. (2012). Prediction of kernel density of corn using singlekernel near infrared spectroscopy. Transactions.

Akbar, M. and Khan, M.I., 2002. Effect of row orientation on yield and yield components of maize. Pakistan J. Agric. Res. 17(2), 186-189.

Bullock, D. G., Raymer, P. L., and Savage, S. 1989. Variation of protein and fat concentration among commercial corn hybrids grown in the southeastern USA. J. Prod. Agric. 2:157-161.

Crasta, O.R. and Dixit, L.A. 1989. Influence of row orientation on the performance of maize and safflower in a sequence cropping. Farming System,5(1-2): 7-11.

Fortin, M. C., and Pierce, F. J. (1996). Leaf azimuth in strip-intercropped corn. Agronomy Journal, 88(1), 6-9.

Genter, C. F., Eheart, J. F., and Linkous, W. N. 1956. Effects of location, hybrid, fertilizer, and rate of planting on the oil and protein content of corn grain. Agron. J. 48:63-67.

Grewal, D.S. 1989 Effect of crop geometry and nitrogen fertility on nutrient uptake in wheat. Annals of Biology. 5(1): 43-47.

Karlen, D. L., and Kasperbauer, M. J. (1989). Row orientation and configuration effects on canopy light spectra and corn growth [electronic resource]. Applied Agricultural Research, 4(1), 51-56. 
Maddonni, G. A., Cirilo, A. G., and Otegui, M. E. (2006). Row width and maize grain yield. Agronomy journal, 98(6), 1532-1543.

Nielsen, R.L. 2001. Stand establishment variability in corn [Online].Available at: http://www.agry.purdue.edu/ext/pubs/AGRY-91-01_v5.pdf [modified Nov. 2001; verified 1 Dec. 2003]. Publ. AGRY-91-1.. Dep. of Agronomy, Purdue Univ., West Lafayette, IN.

Porter, P., D. Hicks, W. Lueschen, J. Ford, D. Warnes and T. Hoverstad. 1997. Corn response to row width and plant population in the northern Corn Belt. J. Prod. Agric. 10:293-300.

Toler, J. E., Wallace, S. U., Stapleton, G. S., \& Murdock, E. C. (1999). Corn leaf orientation effects on light interception, intraspecific competition, and grain yields. Journal Of Production Agriculture, 12(3), 396-399.

Tollenaar, M., and Lee, E. A. (2002). Yield potential, yield stability and stress tolerance in maize. Field Crops Research, 75(2), 161-169.

Torres, G., Vossenkemper, J., Raun, W., and Taylor, R. (2011). Maize (zea mays) leaf angle and emergence as affected by seed orientation at planting. Experimental Agriculture, 47(04), 579. doi:10.1017/S001447971100038X

United States Department of Agriculture. 2012. Economic Research Service. Available online:

http://www.ers.usda.gov/datafiles/Feed_Grains_Yearbook_Tables/All_tables_in_ one file/fgyearbooktablesfull.pdf. Accessed January 17, 2013. 
Valentinuz, O. R., and Tollenaar, M. (2004). Vertical profile of leaf senescence during the grain-filling period in older and newer maize hybrids. Crop Science, 44(3), 827-834.

Widdicombe, W. D., and Thelen, K. D. (2002). Row width and plant density effects on corn grain production in the northern corn belt. Agronomy Journal, 94(5), 10201023. 


\title{
CHAPTER IV \\ IMPACT OF ORIENTATION OF PLANTED MAIZE SEEDS ON COMPOSITION AND FEEDING VALUE OF MAIZE PLANTS
}

\begin{abstract}
Maize seeds emerge faster when planted seeds have their tip oriented downward. With such kernels, the first leaf emerges on the germ side of planted seeds. Through altering interplant and inter-row shading, spatial seed orientation may alter composition, yield and feeding value of plants. In 2011, 12 rows of two Pioneer hybrids at $69 \mathrm{~K}$ and $84 \mathrm{~K}$ plants per hectare were planted either randomly $(\mathrm{R})$ with a mechanical maize planter or manually with kernel points downward with the germ of each kernel either facing other seeds within the same row (W) or facing adjacent rows of maize (A) in an alternating fashion. Plants were harvested on two harvest dates. When harvested at $33 \%$ plant DM, plant DM and grain yields for oriented kernels (average of W and A) were 16 and $27 \%$ greater $(P \leq 0.05)$ than for $\mathrm{R}$. Because plant composition was not altered, milk per ton (Milk2006) was not altered by seed orientation, but because plant yield was increased, predicted milk per hectare was $27 \%$ greater when kernels had been planted with their tips downward. When harvested at 42\% DM, plant and grain weights were 29 and $20 \%$ greater $(P<0.05)$ for $\mathrm{W}$ than $\mathrm{R}$ leading to $15 \%$ greater $(P \leq 0.05)$ predicted milk per hectare. In 2012, similar seed orientations and plant populations were tested using three Pioneer hybrids harvested on a single date (41\% plant DM). Angles of the


first and the ear leaf relative to the germ were measured for 160 plants of each seed orientation. The first leaf emerged parallel to the germ azimuth $(0.7 \pm 32.8$ degrees $)$. Plant dry weights were $25 \%$ greater $(P \leq 0.05)$ for A than R and ADF content and digestible NDF were 5 and $3 \%$ greater $(P \leq 0.05)$ for A than R. Silage and grain yields were 25 and $29 \%$ greater for A than R leading to estimates of $2 \%$ more milk per ton and $29 \%$ more $(P \leq 0.05)$ milk per hectare. At harvest, the number of dead leaves and husks was greatest $(P \leq 0.05)$ for $\mathrm{R}$ plants. Spatial orientation of planted maize seeds, presumably through speeding emergence time, reducing interplant competition, and increasing capture of sunlight by leaves, increased biomass production that in turn increased projected milk yield.

Keywords: Silage, seed, orientation

\section{Introduction}

In recent years, maize silage has become the forage of choice for many livestock producers due to high maize yields the high energy content of maize silage. Compared with grazing forages, ensiling allows a palatable, nutritious feed source to be fed all year around. Genetic advances and technology in the seed industry has increased the ability of maize plants to thrive in growing conditions and withstand increased biotic and abiotic stressors (Tollenaar and Lee, 2002). One physiological change has been development of plants with a high prevalence of upright leaves that allow more light to reach deeper into the canopy and reach the lower plant leaves. Similarly, light penetration can be altered by orientation of plant by the direction in which the maize rows are planted (Karlen and Kasperbauer, 1989) or by the direction of plant leaves that can be altered by specifically 
orienting the maize kernels in soil when seeds are planted (Fortin and Pierce, 1996). As plant population increases, the ratio of grain to stover decreases; this reduces lowering the digestible energy content of silage (Rutger and Crowder, 1967). Lorenz et al. (2007) observed that compared with hybrids grown in past decades, the heavier, healthier plants from modern hybrids are able to withstand the increased level of stress associated with much higher plant populations and as a result will have increased yields of both plant DM (silage) and grain at a higher plant populations.

The hypothesis tested in these studies was that controlling the orientation of maize kernels in the soil would control leaf orientation and orientation of leaves that in turn would alter silage yield. The presumption was that plants with leaves facing adjacent rows would have greater silage yield than plants with random leaf orientation whereas plants with leaves facing other plants within the same row would have lower silage yields than randomly planted kernels. Therefore, the objective of this study was to compare plant DM yield of plants whose kernels had been hand-planted at specific kernel orientations as compared with kernels planted with a conventional maize planter. Plant yields were measured and assayed for starch, NDF, ADF, WPDIG, soluble sugar, CP, residual DM, ash, and dNDF.

Materials and methods

\section{Experiment 1}

During the 2011 growing season two Pioneer maize silage hybrids were grown in plots within a field where kernels were either planted manually in specific orientations or planted with a conventional maize planter. Rows ran in an east-west direction. Plots 
were $4.7 \mathrm{~m}$ long by $9.12 \mathrm{~m}$ wide (12 rows wide with a $0.76-\mathrm{m}$ intra-row spacing) within a single field at the Illinois State University research farm in Lexington, IL. Individual plots consisted of six rows of a single hybrid at a single plant population where kernels were hand planted in one of two directions with the germ either facing adjacent rows or facing plants within the row or planted randomly with a conventional maize planter. Each treatment was replicated and planted to achieve either a lower plant population $(69,000$ plants ha ${ }^{-1}$ ) or a higher plant population $\left(84,000\right.$ plants ha $\left.{ }^{-1}\right)$. A John Deere 7000 (Moline, IL) conventional maize planter was used to achieve a random seed placement in the soil. Randomly planted rows were grown adjacent to hand rows at the same populations and also were replicated within rows in a north south direction adjacent to hand planted plots.

\section{Mechanics of Hand Planting}

To achieve specific orientations of kernels being planted, individual kernels were loaded into straws that in turn were spatially oriented within planting jigs that controlled both plant spacing and seed orientation within the plant row. First, individual kernels were placed in soda straws that were $21 \mathrm{~cm}$ long with a $0.7 \mathrm{~cm}$ internal diameter. Each straw had a red line on one side of the straw. The germ of each kernel was aligned with this red line of each straw. Kernels of each hybrid were loaded into straws at least 4 weeks prior to being planted. For planting, 16 wooden jigs $117.5 \mathrm{~cm}$ in length and $16 \mathrm{~cm}$ in height were constructed. Eight of these jigs had holes spaced at 18.97-cm whereas eight had holes spaced at $15.62-\mathrm{cm}$ so that kernels being planted had plant populations of 69,000 plants ha ${ }^{-1}$ and 84,000 plants ha ${ }^{-1}$, respectively. Once the boards were laid on the 
soil at the proper location within the desired row, each straw was placed into a hole in the jig until the top of the straw was aligned with the top jig (so that the tip of the straw was 5 $\mathrm{cm}$ below the surface of the soil). The red line on each straw was aligned with a red mark on the jig so that the germ of each kernel was oriented in the desired direction. Finally, a wooden dowel the same length as the straws was pushed into each straw as a plunger to plant each seed into the soil without altering the orientation of the kernel. The red marks on four of the jigs were parallel with the length of the jig so that the germ of adjacent plants all faced the same direction and faced other seeds within the row. The other two jigs had red lines that alternately faced adjacent rows so that germs all faced kernels in adjacent rows but in an alternating fashion.

\section{Silage harvest}

Two sets of five-randomly selected, plants were harvested from the center two rows within each seed orientation, plant population, hybrid, and row direction when plants contained about 33\% DM and again when plants contained about 42\% DM. Dead leaves for each set of plants were recorded, and plants were weighed. Each set of plants was ground using an Echo Engine-Driven Chipper/Shredder Model SC3206 (West Fargo, North Dakota) through a $1.9 \mathrm{~cm}$ hole grate. Whole chopped plant samples from each set were collected and mixed thoroughly. After mixing, two samples were collected and frozen for later analysis. Samples were assayed by NIR procedures standardized by DuPont Pioneer (Johnston, Iowa) for starch, NDF, ADF, WPDIG, soluble sugar, CP, residual DM, ash, and dNDF.

\section{Experiment 2}


During the 2012 growing season (Exp 2) three Pioneer maize silage hybrids were grown in hand planted plots measuring 4.7 meters long by $9.12 \mathrm{~m}$ wide (12 rows wide in 0.76-m row spacing) and in mechanically planted plots at the Illinois State University research farm in Normal, IL. Six rows of each plot were hand planted by similar methods as described for Exp 1. Each seed orientation, plant population, and row direction was replicated at a low population of 69,000 plants $^{-1} \mathrm{a}^{-1}$ and at a high population of 84,000 plants ha ${ }^{-1}$. A conventional John Deere 7000 maize planter (Moline, IL) was used to achieve random seed placement in the soil in rows adjacent to hand planted rows. All treatments were replicated in NS and EW rows.

\section{Silage harvest}

Two sets of five randomly selected plants were harvested from the center two rows of each treatment. Dead leaves for each set of plants were recorded, and plants were weighed. Sets of plants were ground using an Echo Engine-Driven Chipper/Shredder Model SC3206 (West Fargo, North Dakota) with a $1.9 \mathrm{~cm}$ hole grate. Whole chopped plant samples from each set were collected and mixed thoroughly. After mixing, two samples were collected and frozen for later analysis. Samples were assayed by NIR procedures standardized by DuPont Pioneer (Johnston, Iowa) for starch, NDF, ADF, WPDIG, soluble sugar, CP, residual DM, ash, and dNDF.

\section{Statistical Analysis}

Analysis of variance for a fixed factorial was used for experiment 1 using SAS version 9.2 (SAS Inst., Cary, NC). All treatment factors in the experiment were considered as fixed effects. Randomly planted rows in the NS row orientation were 
compared to EW randomly planted rows separately from the hand planted treatments in Exp 1. In Exp 2 all factors were considered to be fixed effects with all treatments compared as a single factorial experiment. Orthogonal contrasts were employed to separate the effect of kernel tip orientation from the effect of germ direction. For testing the kernel tip effect, the response to random planted kernels was compared with the response to germ oriented kernels. For testing the germ direction effect, the response to kernels with germs facing other rows was compared to the response to kernels with germs facing other plants within the same row.

\section{Results and Discussion}

\section{Experiment 1}

When whole plants were harvested at 33\% plant DM, yield of plant DM of was $19 \%$ greater $(\mathrm{P}<0.01)$ for plants whose seeds were planted with germs oriented acrossrow orientation than with germs oriented randomly. Similarly, yield was $11 \%$ greater (P $<0.01)$ for plants whose seeds were planted with germs oriented within-row than for plants with germs oriented randomly. Grain yield, calculated from starch content of plant DM assuming grain contained 70\% starch, was increased $9 \%$ and 3\% ( $P=0.0074)$ greater for across row and with row orientations as compared to randomly planted kernels. About $50 \%$ of the DM of a maize plant should be grain when plants are mature. Plant composition was not altered by seed orientation treatments (Table 7). Lorenz et al. (2007) observed similar results with both grain and plant weight yields increasing when specific seed orientations were used. Based on plant composition, milk per ton of silage DM (Milk2006) did not differ between treatments $(P=0.5387)$ reflecting the similarity in plant 
composition of plants from all seed orientations. Similar conclusions were drawn by Lorenz et al. (2007). Yet, because of the higher DM yield with similar nutrient compositions, calculated milk per hectare was $22 \%$ greater for across row orientation and $16 \%(P=0.0015)$ greater for within row seed orientations compared to randomly planted kernels.

When two hand planted treatments (kernels tip down) were compared to randomly planted kernels, plant wet weight was $18 \%$ greater $(P<0.0001)$ and plant dry weight $15 \%$ greater $(P<0.0001)$. Increases in plant weight should result in $15 \%$ greater $(P<0.0001)$ silage yield per hectare. Grain yield also was $6 \%$ greater $(P=0.0026)$ for kernels planted tip down compared to randomly planted kernels. Yet, because of higher DM yield with similar nutrient composition, calculated milk per ton did not differ $(P=0.3086)$ even though milk per hectare was $19 \%$ greater $(P=0.0006)$ for kernels planted tip down.

The two hand planted treatments were compared to observe differences between germ orientations while being planted tip down in the soil. Plant wet weights and dry weights were greater for across row germ orientation compared to with row orientation $(P=0.0345)$ and $(P=0.0055)$, respectively. Silage yield per hectare was $7 \%$ greater $(P=0.0056)$ for across row germ orientation compared to within row germ orientation. Other factors measured did not differ and calculated milk per hectare and per ton did not differ with germ orientation (Table 7).

Whole plants were harvested on a second date when plants contained about $42 \%$ DM. At this time, DM yield was $14 \%$ greater for plants whose seeds had been planted 
with germs oriented within-row orientation and by $4 \%(P=0.0509)$ for plants whose seeds had been planted across-rows when compared with seeds planted randomly. Grain yield from across-row planted seeds was $20 \%$ greater $(P=0.0364)$ than randomly planted kernels. This increase in grain yield when combined with the increase in DM yield resulted in a $15 \%$ increase in expected milk yield per hectare for within-row seed orientation compared to randomly planted kernels. However, plant composition was not altered (Table 8$)$, so expected milk per ton of silage DM did not differ $(P=0.9648)$ among seed orientations.

\section{Experiment 2}

When kernels were planted by hand with their tip downward, $89 \%$ of the first leaves emerged within $45^{\circ}$ of being parallel to the germ. These observations are similar to those of Fortin and Pierce (1996) who observed that 60-74\% of the time, the early leaves of maize plants grew parallel to the direction of the germ when kernel orientation was controlled at planting. Leaf angles were measured again when plants had formed a definitive ear (R1). At this time, only $31 \%$ of plants' ear leaves remained within $45^{\circ}$ of being parallel to the germ. One would expect that $12.5 \%$ of leaves would be within each 45\% quadrant had leaf orientation been random. Maddonni et al. (2002) observed that plants will reorient their leaves when competing for light with neighboring plants.

When plants were harvested at $44 \%$ DM, plant dry weight was $25 \%$ greater $(P<0.0001)$ for plants whose seeds had been oriented across row and $19 \%$ greater $(P<0.0001)$ for plants whose seeds had been oriented within row when compared with plants with randomly planted kernels (Table 9). Grain yield, calculated from starch 
content of plant DM, was $30 \%$ greater $(P<0.0001)$ for the across-row seed orientation than randomly planted kernels. Toler et al. (1999) also observed greater grain yield for plants whose seed germs had been oriented across-row as compared to random seed orientation. Plant composition was not altered for seed orientation treatments. Consequently, seed orientation did not alter milk per ton $(P=0.1421)$. But due to the increased plant DM yield, predicted milk per hectare was $29 \%$ greater $(P<0.0001)$ for the across-row seed orientation as compared with randomly planted kernels.

Seed orientation did not alter the number of dead leaves per plant, the percentage of dead husks per treatment, \%ADF, or milk per ton. However, when analyzed using ttest, post-hoc test procedures, treatment differences were detected (Table 10). Dead leaves per plant were $24 \%$ greater $(P=0.01)$ for plants from kernels planted randomly than from plants whose kernel germs had been oriented across-rows. Greater grain yield of plants with fewer dead leaves disagrees with results of Dwyer and Stewart (1986) that compared these two factors with multiple hybrids. They observed that as grain yield increased, leaf senescence also increased so they suggested that plants using more nutrients for grain production depleted reserves from leaves resulting in leaf senescence. Instead, results from the current study could be interpreted to imply that shading of lower leaves by upper leaves may be responsible for senescence of the lower leaves. The percentage of dead husks also was $14 \%$ greater $(P=0.05)$ for plants from randomly planted kernels than plants from across-row orientated kernels. Concentration of ADF was $5 \%$ greater $(P=0.03)$ for randomly planted kernels than across-row orientated kernels. Milk per ton was $2 \%$ greater $(P=0.05)$ for across-row orientated kernels than randomly planted kernels. 
When kernels planted tip down were compared to those randomly planted, plant wet weight was $24 \%$ greater $(P<0.0001)$ and plant dry weight was $22 \%$ greater $(P<0.0001)$ for kernels planted tip down. Content of ADF was 5\% less $(P=0.0339)$ for kernels that were planted tip down compared to randomly planted kernels. Silage yield per hectare was $22 \%$ greater $(P<0.0001)$ and grain yield per hectare $26 \%$ greater $(P<0.0001)$ for kernels planted tip down. Nutrient composition was similar for tip down and randomly planted (Table 9), therefore, milk per ton was not altered, however milk per hectare was $24 \%$ greaer $(P<0.0001)$ for kernels planted tip down. The two hand planted treatments were compared to each other, milk per hectare was $7 \%$ greater $(P=0.0416)$. All other factors evaluated were not different between across and with row orientations (Table 9).

\section{Conclusions}

Results of this study support the hypothesis that orienting plant leaves within crop rows will increase silage yield. Kernels planted in across-row orientation increased plant DM yield and grain yield per hectare. Milk per ton was not altered in Exp1 by seed orientation treatments but in Exp2 milk per ton was greater with across row orientated kernels than randomly planted kernels. Milk per hectare was increased for across row orientation in both experiments when compared to randomly planted kernels.

\section{Implications}

Through orienting maize kernels at planting, direction of the first leaves produced by the maize plant can be controlled. But as plants compete for light and nutrients, the direction of the leaves within the row can be altered by growing conditions. Grain yield 
was significantly greater when kernels were specifically oriented when planted, presumably because interplant competition was reduced so that sunlight penetrated deeper into the canopy to contact ear leaves that play a vital role in grain filling. Orientation of maize kernels during planting currently is limited by planter technology. Modern maize planters do not precisely place kernels into the soil with their points downward and their germ facing a specific direction. Instead, kernels are from a seed meter so kernel orientation essentially is random. If further research confirms the increased grain and silage yields observed in this and other studies, engineers designing maize planting equipment would be expected to develop planters with seed orientation technology that would benefit both grain and silage growers. 
TABLES FOR CHAPTER IV: IMPACT OF ORIENTATION OF PLANTED MAIZE SEEDS ON COMPOSITION AND FEEDING

\section{VALUE OF MAIZE PLANTS}

Table 7. Effects of seed orientation on silage yield and composition when harvested at approximately $33 \% \mathrm{DM}$ in Trial 1.

\begin{tabular}{|c|c|c|c|c|c|c|}
\hline \multirow[b]{2}{*}{ Variable } & \multicolumn{3}{|c|}{ Seed orientation ${ }^{1}$} & \multirow{2}{*}{$\begin{array}{c}P \text {-value } \\
\text { TRT }\end{array}$} & \multirow{2}{*}{$\frac{P \text {-value }}{\text { Tip down }}$} & \multirow{2}{*}{$\frac{P \text {-value }}{\text { Germ }}$} \\
\hline & Across-row & With-row & Randomly planted & & & \\
\hline Plant DM, \% & 33.2 & 32.5 & 33.4 & 0.4385 & 0.3758 & 0.3573 \\
\hline Plant wet weight, g & $818.8^{\mathrm{a}}$ & $778.8^{\mathrm{ab}}$ & $673.8^{\mathrm{b}}$ & $<0.0001$ & $<0.0001$ & 0.0345 \\
\hline Plant dry weight, g & $271.1^{\mathrm{a}}$ & $252.1^{\mathrm{b}}$ & $226.3^{\mathrm{c}}$ & $<0.0001$ & $<0.0001$ & 0.0055 \\
\hline Starch, \% & 29.5 & 30.0 & 27.3 & 0.3246 & 0.1504 & 0.7769 \\
\hline Soluble sugars, \% & 12.8 & 12.5 & 12.9 & 0.9075 & 0.7800 & 0.7440 \\
\hline $\mathrm{CP}, \%$ & 7.4 & 7.5 & 7.5 & 0.8149 & 0.5889 & 0.7537 \\
\hline Ash, \% & 3.1 & 3.1 & 3.4 & 0.0691 & 0.0244 & 0.9303 \\
\hline $\mathrm{ADF}, \%$ & 20.9 & 21.1 & 22.4 & 0.1559 & 0.0619 & 0.8087 \\
\hline NDF, $\%$ & 37.9 & 37.7 & 39.85 & 0.2288 & 0.0956 & 0.8789 \\
\hline dNDF, $\%$ of NDF & 48.8 & 50.0 & 48.6 & 0.8201 & 0.6009 & 0.7461 \\
\hline $\begin{array}{l}\text { Silage yield, metric } \\
\text { tons DM/ha }\end{array}$ & $10.4^{\mathrm{a}}$ & $9.7^{\mathrm{b}}$ & $8.7^{\mathrm{c}}$ & 0.0001 & $<0.0001$ & 0.0056 \\
\hline $\begin{array}{l}\text { Grain, metric tons } \\
\text { DM/ha } \\
\text { Milk } 2006 \\
\text { calculations }\end{array}$ & 7.2 & 6.8 & $6.6^{\mathrm{b}}$ & 0.0074 & 0.0026 & 0.3767 \\
\hline Per hectare & 29547.5 & 27936.0 & $24059.2^{\mathrm{b}}$ & 0.0015 & 0.0006 & 0.1585 \\
\hline Per ton & 3167.0 & 3210.2 & 3088.3 & 0.5387 & 0.3086 & 0.6971 \\
\hline
\end{tabular}

${ }^{\mathrm{abc}}$ Means within a row with different superscripts differ significantly $(P<0.05)$. 
${ }^{1}$ Seed orientation: Across-row= Kernel planted with germ facing adjacent row; With-row=Kernel planted with germ facing adjacent kernels in same row, Randomly planted= Kernel planted with conventional planter.

${ }^{2} P$-value: TRT=Main effect of treatment

${ }^{3} P$-value: Tip down= Average of Across row and With row planted tip down compared to Randomly planted

${ }^{4} P$-value: Germ=Across row compared to With row controlled orientation of germ 
Table 8. Effects of seed orientation on silage yield and composition when harvested at approximately $42 \%$ DM in Trial 1

\begin{tabular}{|c|c|c|c|c|c|c|}
\hline \multirow[b]{2}{*}{ Variable } & \multicolumn{3}{|c|}{ Seed orientation $^{1}$} & \multirow{2}{*}{$\frac{P \text {-value }}{2}$} & \multirow{2}{*}{$\begin{array}{c}P \text {-value } \\
\text { Tip down }\end{array}$} & \multirow{2}{*}{$\frac{P \text {-value }}{4}$} \\
\hline & Across-row & With-row & Randomly planted & & & \\
\hline Plant DM, \% & 41.6 & 43.5 & 42.8 & 0.4842 & 0.8693 & 0.2409 \\
\hline Plant wet weight, $g$ & 595.0 & 652.5 & 570.0 & 0.0889 & 0.0996 & 0.1245 \\
\hline Plant dry weight, $\mathrm{g}$ & 245.9 & $285.4^{\mathrm{a}}$ & 244.6 & 0.0509 & 0.1760 & 0.0358 \\
\hline Starch, \% & 32.9 & 34.7 & 33.2 & 0.2941 & 0.5590 & 0.1503 \\
\hline Soluble sugars, \% & 9.1 & 7.9 & 8.0 & 0.2437 & 0.4221 & 0.1403 \\
\hline $\mathrm{CP}, \%$ & $7.8^{\mathrm{b}}$ & 8.1 & 8.2 & 0.0478 & 0.0492 & 0.1065 \\
\hline Ash, \% & 3.3 & 3.2 & 3.5 & 0.2836 & 0.1353 & 0.6254 \\
\hline $\mathrm{ADF}, \%$ & 20.5 & 20.8 & 21.7 & 0.3226 & 0.1455 & 0.7821 \\
\hline $\mathrm{NDF}, \%$ & 38.1 & 37.8 & 38.6 & 0.7781 & 0.5159 & 0.8000 \\
\hline $\mathrm{dNDF}, \%$ of $\mathrm{NDF}$ & 47.8 & 47.1 & 47.6 & 0.1909 & 0.5106 & 0.0916 \\
\hline $\begin{array}{l}\text { Silage yield, Metric } \\
\text { tons DM/ha }\end{array}$ & 9.72 & $10.92^{\mathrm{a}}$ & 9.35 & 0.0447 & 0.1828 & 0.0297 \\
\hline $\begin{array}{l}\text { Grain, metric tons } \\
\mathrm{DM} / \mathrm{ha}\end{array}$ & 7.2 & $8.8^{\mathrm{a}}$ & 7.3 & 0.0364 & 0.2109 & 0.0210 \\
\hline $\begin{array}{l}\text { Calculated Milk } \\
2006\end{array}$ & & & & & & \\
\hline Per hectare & 27539.9 & $31905.5^{\mathrm{a}}$ & 27664.5 & 0.0541 & 0.2192 & 0.0331 \\
\hline Per ton & 3289.8 & 3283.9 & 3302.1 & 0.9648 & 0.8027 & 0.9341 \\
\hline
\end{tabular}

${ }^{a b c}$ Means within a row with different superscripts differ significantly $(P<0.05)$.

${ }^{1}$ Seed orientation: Across-row= Kernel planted with germ facing adjacent row; With-row=Kernel planted with germ facing adjacent kernels in same row, Randomly planted= Kernel planted with conventional planter.

${ }^{2} P$-value: TRT=Main effect of treatment 
${ }^{3} P$-value: Tip down $=$ Average of Across row and With row planted tip down compared to Randomly planted

${ }^{4} P$-value: Germ=Across row compared to With row controlled orientation of germ 
Table 9. Effects of seed orientation on silage yield and composition in Trial 2

\begin{tabular}{|c|c|c|c|c|c|c|}
\hline \multirow[b]{2}{*}{ Variable } & \multicolumn{3}{|c|}{ Seed orientation ${ }^{1}$} & \multirow{2}{*}{$\begin{array}{c}P \text {-value } \\
\text { TRT }\end{array}$} & \multirow{2}{*}{$\frac{P \text {-value }}{3}$} & \multirow{2}{*}{$\begin{array}{c}P \text {-value } \\
\text { Germ }\end{array}$} \\
\hline & Across-row & With-row & $\begin{array}{l}\text { Randomly } \\
\text { planted }\end{array}$ & & & \\
\hline Plant DM, \% & 44.0 & 44.0 & 44.5 & 0.7023 & 0.4117 & 0.8685 \\
\hline $\begin{array}{l}\text { Dead leaves per } \\
\text { plant }\end{array}$ & 4.3 & 4.3 & 4.9 & 0.1659 & 0.0590 & \\
\hline Dead husks, \% & 71.0 & 70.0 & 85.0 & 0.1052 & 0.0348 & 0.9153 \\
\hline Plant wet weight, g & $757.0^{\mathrm{a}}$ & $723.0^{\mathrm{a}}$ & 597.0 & $<0.0001$ & $<0.0001$ & 0.2086 \\
\hline Plant dry weight, $g$ & $310.0^{\mathrm{a}}$ & $295.0^{\mathrm{a}}$ & 248.0 & $<0.0001$ & $<0.0001$ & 0.0776 \\
\hline Starch, \% & 36.3 & 35.4 & 35.2 & 0.5282 & 0.4578 & 0.3957 \\
\hline Soluble sugars, $\%$ & 7.9 & 7.6 & 7.5 & 0.8303 & 0.6249 & 0.7179 \\
\hline $\mathrm{CP}, \%$ & 7.6 & 7.7 & 7.6 & 0.7128 & 0.5390 & 0.5864 \\
\hline Ash, \% & 3.1 & 3.2 & 3.3 & 0.4475 & 0.3436 & 0.3999 \\
\hline $\mathrm{ADF}, \%$ & 21.5 & 21.8 & 22.7 & 0.0818 & 0.0339 & 0.4790 \\
\hline $\mathrm{NDF}, \%$ & 37.5 & 38.1 & 38.8 & 0.3011 & 0.1642 & 0.4973 \\
\hline $\mathrm{dNDF}, \%$ of NDF & 47.5 & 47.4 & 47.5 & 0.9589 & 0.9266 & 0.7846 \\
\hline $\begin{array}{l}\text { Silage yield, Metric } \\
\text { tons DM/ha }\end{array}$ & $11.8^{\mathrm{a}}$ & $11.2^{\mathrm{ab}}$ & $9.4^{\mathrm{b}}$ & $<0.0001$ & $<0.0001$ & 0.0574 \\
\hline $\begin{array}{l}\text { Grain, metric tons } \\
\text { DM/ha } \\
\text { Milk } 2006 \\
\text { calculations }\end{array}$ & $12.3^{\mathrm{a}}$ & $11.4^{\mathrm{a}}$ & 9.4 & $<0.0001$ & $<0.0001$ & 0.0673 \\
\hline Per hectare & $35248^{\mathrm{a}}$ & $33014^{\mathrm{b}}$ & $27425^{\mathrm{c}}$ & $<0.0001$ & $<0.0001$ & 0.0416 \\
\hline Per ton & 3339 & 3299 & 3273 & 0.1421 & 0.1147 & 0.2304 \\
\hline
\end{tabular}

${ }^{\text {abc }}$ Means within a row with different superscripts differ significantly $(P<0.05)$.

${ }^{1}$ Seed orientation: Across-row= Kernel planted with germ facing adjacent row; With-row=Kernel planted with germ facing adjacent kernels in same row, Randomly planted= Kernel planted with conventional planter.

${ }^{2} P$-value: TRT $=$ Main effect of treatment

${ }^{3} P$-value: Tip down= Average of Across row and With row planted tip down compared to Randomly planted

${ }^{4} P$-value: Germ=Across row compared to With row controlled orientation of germ 
Table 10. Analysis of across row and randomly planted treatments analyzed within treatment using t-test comparisons in Trial 2

\begin{tabular}{lccc}
\hline \hline \multirow{1}{*}{ Variable } & \multicolumn{2}{c}{ Seed orientation } & $P$-value \\
\cline { 2 - 4 } & Across-row & Randomly planted & TRT \\
\hline Dead leaves per plant & 4.3 & $4.9^{\mathrm{a}}$ & 0.01 \\
Dead husks, \% & 71.0 & $85.0^{\mathrm{a}}$ & 0.05 \\
ADF, \% & 21.5 & $22.7^{\mathrm{a}}$ & 0.03 \\
Milk 2006 calculations & $3339^{\mathrm{a}}$ & 3273 & 0.05 \\
Per ton & & \\
\hline abc Means within a row with different superscripts differ significantly $(P<0.05)$. \\
${ }^{1}$ Seed orientation: Across-row= Kernel planted with germ facing adjacent row, Randomly \\
planted= Kernel planted with conventional planter. \\
${ }^{2} P$-value: TRT=Differences within main effect of treatment using t-test comparisons
\end{tabular}




\section{Literature Cited}

Dwyer, L. M., \& Stewart, D. W. (1986). Leaf area development in field-grown maize. Agronomy Journal, 78(2), 334-343.

Fortin, M. C., \& Pierce, F. J. (1996). Leaf Azimuth in Strip-Intercropped Corn. Agronomy Journal, 88(1), 6-9.

Karlen, D. L., and Kasperbauer, M. J. (1989). Row orientation and configuration effects on canopy light spectra and corn growth [electronic resource]. Applied Agricultural Research, 4(1), 51-56.

Lorenz, A., Gustafson, T., de Leon, N., \& Coors, J. (2007). Breeding Maize for Total Biomass Production: Examination of Harvest Index and the Relationship between Stover Yield and Grain Yield.

Maddonni, G. A., Otegui, M. E., Andrieu, B., Chelle, M., \& Casal, J. J. (2002). Maize leaves turn away from neighbors. Plant Physiology, 130(3), 1181-1189.

Millner, J. P., Aver, R. V., \& Hardacre, A. K. (2005). The yield and nutritive value of maize hybrids grown for silage. New Zealand Journal of Agricultural Research, 48(1), 101-108.

Rutger, J. N., \& Crowder, L. V. (1967a). Effect of high plant density on silage and grain yields of six corn hybrids. Crop Science, 7(3), 182-184.

Toler, J. E., Wallace, S. U., Stapleton, G. S., \& Murdock, E. C. (1999). Corn leaf orientation effects on light interception, intraspecific competition, and grain yields. Journal Of Production Agriculture, 12(3), 396-399. 
Tollenaar, M., and Lee, E. A. (2002). Yield potential, yield stability and stress tolerance in maize. Field Crops Research, 75(2), 161-169. 


\section{CHAPTER V \\ SUMMARY AND SYNOPSIS}

Orientation of maize kernels in the soil can influence germination, emergence time, and the spatial orientation of leaves of plants within the canopy. Leaf arrangements can alter how much sunlight penetrates into the lower leaves of maize plants. New practices can only be adopted when technology becomes available to producers. In the research presented in this thesis, results indicate that grain yields and silage yields can be increased by specifically controlling the orientation of kernels as they are planted into soil and by the direction of rows within a field.

The first study compared yields of maize planted with a conventional maize planter with maize planted with specifically controlled seed orientations at planting. The impact of row direction on grain yield and kernel composition also was determined. Rows planted in NS rows had greater grain yields and kernel weights when compared to rows planted EW. Kernels that were planted tip down but with germs facing adjacent rows had greater grain yield and kernel density than randomly planted kernels. Increased planting population increased grain yield with all seed orientations and row directions. These findings indicate that grain yield can be increased by controlling both the orientation of maize kernels when they are planted and the direction of maize rows.

The second study examined the effects of seed orientation on plant (ensilage) yield and composition. Specifically controlling the orientation of kernels being planted 
resulted in an increased plant weights at the time of silage harvest. Planting kernels with their germs facing adjacent rows increased silage yield when compared to kernels planted with a conventional planter. Silage composition was not changed by planting treatments, but because plant yield was increased, projected milk per hectare from harvested plants (silage) was increased. These findings suggest that controlling the orientation of kernels at planting can increase silage yield and thereby increase milk produced per hectare of corn silage harvested while not changing milk per ton of silage.

As the world population and living costs increase, maize producers strive to develop and implement new production practices to increase yields and obtain higher profits with similar inputs. Grain and livestock producers should be proactive when implementing new planting techniques that can increase production. Research efforts to identify and implement these novel planting methods should allow producers to continue to remain profitable and supply consumers with an adequate corn supply to serve as a source of fuel and, when fed to livestock, a source of food. 


\section{REFERENCES}

Albrecht, K. A., Martin, M. J., Russel, W. A., Wedin, W. F., \& Buxton, D. R. (1986). Chemical and in vitro digestible dry matter composition of maize stalks after selection for stalk strength and stalk-rot resistance. Crop science, 26(5), 10511055.

Allen, L. H. (1974). Model of light penetration into a wide-row crop. Agronomy Journal, $66(1), 41-47$.

Armstrong, P., \& Tallada, J. (2012). Prediction of kernel density of corn using singlekernel near infrared spectroscopy. Transactions.

Borger, C. D., Pathan, S., \& Hashem, A. (2010). Manipulating Crop Row Orientation to Suppress Weeds and Increase Crop Yield [electronic resource]. Weed Science, 58(2), 174-178.

Bullock, D. G., Raymer, P. L., and Savage, S. 1989. Variation of protein and fat concentration among commercial corn hybrids grown in the southeastern USA. J. Prod. Agric. 2:157-161.

Campbell, C. M. (1964). Influence of seed formation of corn on accumulation of vegetative dry matter and stalk strength. Crop Science, 4(1), 31-34. 
Caldwell, D. M., \& Perry, T. W. (1971). Relationships Between Stage of Maturity of the Corn Plant at Time of Harvest for Corn Silage and Chemical Composition< sup> 1, 2</sup>. Journal of Dairy Science, 54(4), 533-536.

Colbert, T. R., Darrah, L. L., \& Zuber, M. S. (1984). Effect of recurrent selection for stalk crushing strength on agronomic characteristics and soluble stalk solids in maize. Crop Science, 24(3), 473-478.

Coors, J. G., Albrecht, K. A., \& Bures, E. J. (1997). Ear-fill effects on yield and quality of silage corn. Crop science, 37(1), 243-247.

Cummins, D. G. (1970). Quality and yield of corn plants and component parts when harvested for silage at different maturity stages. Agronomy Journal, 62(6), 781784.

Cusicanqui, J. A., \& Lauer, J. G. (1999). Plant density and hybrid influence on corn forage yield and quality. Agronomy Journal, 91(6), 911-915.

Darby, H. M., \& Lauer, J. G. (2002). Harvest date and hybrid influence on corn forage yield, quality, and preservation. Agronomy Journal, 94(3), 559-566.

Duncan WG 1975. Maize. In: Evans LT ed. Crop Physiology: some case histories. Cambridge University Press. Pp. 23-50 http://books.google.com/books?id=Yro8AAAAIAAJ\&lpg=PR6\&ots=FRaZ9zN_ SG\&dq=crop $\% 20$ physiology $\% 20$ some $\% 20$ case $\% 20$ histories $\% 20$ duncan $\& 1$ r\&pg= $\mathrm{PA} 36 \# \mathrm{v}=$ onepage $\& \mathrm{q} \& \mathrm{f}=$ false

Eduardo G de Souza, G. A., Orlando, M. A., \& A da Silva, P. (2004). Influência da direção de semeadura do milho nas variáveis reflectância e índice de vegetação verde normalizado. Rev. bras. eng. agríc. ambient., 8(1). 
Fortin, M. C., \& Pierce, F. J. (1996). Leaf azimuth in strip-intercropped corn. Agronomy Journal, 88(1), 6-9.

Girardin, P. H., \& Tollenaar, M. (1994). Effects of intraspecific interference on maize leaf azimuth. Crop science, 34(1), 151-155.

Graybill, J. S., Cox, W. J., \& Otis, D. J. (1991). Yield and quality of forage maize as influenced by hybrid, planting date, and plant density. Agronomy journal, 83(3), $559-564$.

Hashemi-Dezfouli, A., \& Herbert, S. J. (1992). Intensifying plant density response of corn with artificial shade. Agronomy Journal, 84(4), 547-551.

J. P. Millner, R. Vill Aver \& A. K. Hardacre (2005): The yield and nutritive value of maize hybrids grown for silage, New Zealand Journal of Agricultural Research, $48: 1,101-108$

Johnson, R. R., McClure, K. E., Johnson, L. J., Klosterman, E. W., \& Triplett, G. B. (1966). Corn plant maturity. I. Changes in dry matter and protein distribution in corn plants. Agronomy Journal, 58(2), 151-153.

Karlen, D. L., \& Kasperbauer, M. J. (1989). Row orientation and configuration effects on canopy light spectra and corn growth [electronic resource]. Applied Agricultural Research, 4(1), 51-56.

Lauer, J. G., \& Rankin, M. M. (2004). Corn response to within row plant spacing variation. Agronomy Journal, 96(5), 1464-1468.

Lewis, A. L., Cox, W. J., \& Cherney, J. H. (2004). Hybrid, maturity, and cutting height interactions on corn forage yield and quality. Agronomy Journal, 96(1), 267-274. 
Liu, W., M. Tollenaar, G. Stewart, and W. Deen. 2004a. Impact of Planter Type, Planting Speed, and Tillage on Stand Uniformity and Yield of Corn. Agron. J. 96:16681672.

Liu, W., Tollenaar, M., Stewart, G., \& Deen, W. (2004b). Response of corn grain yield to spatial and temporal variability in emergence. Crop Science, 44(3), 847-854.

Liu, W., M. Tollenaar, G. Stewart, and W. Deen. 2004c. Within-row plant spacing variability does not affect corn yield. Agron. J. 96:275-280.

Maddonni, G. A., Cirilo, A. G., \& Otegui, M. E. (2006). Row width and maize grain yield. Agronomy journal, 98(6), 1532-1543.

Maddonni GA, Otegui ME, Andrieu B, Chelle M, Casal JJ. 2002 Maize leaves turn away from neighbors. Plant Physiology;130:1181-1189.

Martin, K. L., Hodgen, P. J., Freeman, K. W., Melchiori, R., Arnall, D. B., Teal, R. K., ... \& Raun, W. R. (2005). Plant-to-plant variability in corn production. Agronomy journal, 97(6), 1603-1611.

Nafziger, E. D., Carter, P. R., \& Graham, E. E. (1991). Response of corn to uneven emergence. Crop Science, 31(3), 811-815.

Nielsen, R.L. 2001. Stand establishment variability in corn [Online].Available at: http://www.agry.purdue.edu/ext/pubs/AGRY-91-01_v5.pdf [modified Nov. 2001; verified 1 Dec. 2003]. Publ. AGRY-91-1.. Dep. of Agronomy, Purdue Univ., West Lafayette, IN.

NRC. 1996. Nutrient Requirements of Dairy Cattle. $7^{\text {th }}$ Ed. Natl. Acad. Press, Washington, DC. 
Patten, G.Pl., D.M. Van Doren Jr. 1970. Effect of seed orientation on emergence and growth of corn. Agron. J. 62:592-595.

Porter, P., D. Hicks, W. Lueschen, J. Ford, D. Warnes and T. Hoverstad. 1997. Corn response to row width and plant population in the northern Corn Belt. J. Prod. Agric. 10:293-300.

Rutger, J. N., \& Crowder, L. V. (1967a). Effect of high plant density on silage and grain yields of six corn hybrids. Crop Science, 7(3), 182-184.

Rutger, J. N., \& Crowder, L. V. (1967b). Effect of population and row width on corn silage yields. Agronomy journal, 59(5), 475-476.

Shapiro, C. A., \& Wortmann, C. S. (2006). Corn Response to Nitrogen Rate, Row Spacing, and Plant Density in Eastern Nebraska [electronic resource]. Agronomy Journal, 98(3), 529-535.

Steiner, J. L. (1986). Dryland grain sorghum water use, light interception, and growth responses to planting geometry. Agronomy journal, 78(4), 720-726.

Teasdale, J. R. (1998). Influence of corn (Zea mays) population and row spacing on corn and velvetleaf (Abutilon theophrasti) yield. Weed Science, 46(4), 447-453.

Thomison, P.R. and A.B. Geyer. 2009. Corn response to differential removal of leaves from the upper and lower canopy. Available at www.plantmanagementnetwork.org/cm/ Crop Management

Toler, J. E., Wallace, S. U., Stapleton, G. S., \& Murdock, E. C. (1999). Corn leaf orientation effects on light interception, intraspecific competition, and grain yields. Journal Of Production Agriculture, 12(3), 396-399. 
Tollenaar, M., \& Lee, E. A. (2002). Yield potential, yield stability and stress tolerance in maize. Field Crops Research, 75(2), 161-169.

United States Department of Agriculture. 2012. Economic Research Service. Available online:

http://www.ers.usda.gov/datafiles/Feed_Grains_Yearbook_Tables/All_tables_in one file/fgyearbooktablesfull.pdf. Accessed January 17, 2013.

Valentinuz, O. R., \& Tollenaar, M. (2004). Vertical profile of leaf senescence during the grain-filling period in older and newer maize hybrids. Crop Science, 44(3), 827834.

Van Roekel, R. J., \& Coulter, J. A. (2012). Agronomic responses of corn hybrids to row width and plant density. Agronomy Journal, 104(3), 612-620.

Widdicombe, W. D., \& Thelen, K. D. (2002). Row width and plant density effects on corn grain production in the northern corn belt. Agronomy Journal, 94(5), 10201023.

Wiersma, D. W., Carter, P. R., Albrecht, K. A., \& Coors, J. G. (1993). Kernel milkline stage and corn forage yield, quality, and dry matter content. Journal of production agriculture, 6, 94-94. 